\title{
Status of the Names Aeromonas and Aerobacter liquefaciens Beijerinck and Designation of a Neotype Strain for Aeromonas hydrophila Stanier
}

\author{
Request for an Opinion
}

\author{
RALPH H. W. SCHUBERT \\ Abteilung für Hygiene, Hygiene-Institut der \\ Johann Wolfgang Goethe Universität, Frankfurt, Germany
}

\begin{abstract}
Evidence is given that the name Aerobacter liquefaciens Beijerinck 1900 is a nomen dubium, and the Judicial Commission of the International Committee on Systematic Bacteriology is requested to place the name in the list of nomina rejicienda. However, this species is the type species of the genus Aeromonas Kluyver and van Niel 1936. Because the generic name Aeromonas has come into general use for identifiable species named subsequently, the Judicial Commission is requested, in accordance with Rule $9 \mathrm{c}(3)(\mathrm{c})$ of the International Code of Nomenclature of Bacteria (3) to designate Aeromonas hydrophila (Chester 1901) Stanier 1943 as the type species of Aeromonas and to designate Stanier as the author of this generic name. ATCC 7966 is here designated as the neotype strain of Aeromonas hydrophila.
\end{abstract}

In 1900, Beijerinck gave the name Aerobacter liquefaciens to a species of bacterium with a single polar flagellum and with the fermentation characteristics of Aerobacter aerogenes Beijerinck 1900. Kluyver and van Niel (1936) proposed recognition of a genus Aeromonas for polarly flagellated organisms “... which ferment sugars in a way probably closely related to the fermentation type characteristic of the genera Aerobacter and Aerobacillus." The authors named one species in this genus, i.e., the type species, Aeromonas liquefaciens (Beijerinck 1900) Kluyver and van Niel 1936.

Because Beijerinck's strains are no longer extant, the genus Aeromonas must be based on the species description in Beijerinck's paper. The description of Aerobacter liquefaciens differs (8) in some important characteristics from the other species currently recognized as members of the genus Aeromonas. Strains labeled Aeromonas liquefaciens by Kluyver and distributed to other bacteriologists (2) were assigned to Aeromonas hydrophila (Chester 1901) Stanier 1943, and therefore are not in accordance with the description of Aerobacter liquefaciens Beijerinck 1900, or were found to belong to a genus of the family Enterobacteriaceae (2).

Beijerinck obtained his strains from an infusion prepared from rhizomes of Althaea officinalis (marshmallow) which were cut into pieces and incubated at $28 \mathrm{C}$ for 2 days. The author's attempts to isolate a strain conforming to Beijerinck's description from Althaea officinalis were unsuccessful. Because there are no Beijerinck cultures extant of Aerobacter liquefaciens and because there appear to be no strains that can serve as a neotype strain, the type of Aerobacter liquefaciens is Beijerinck's original description. Inasmuch as no known organism fits Beijerinck's description, the name Aerobacter liquefaciens should be designated a nomen dubium.

Because the generic name Aeromonas has come into worldwide use for several well known species, it is proposed to validate the generic name Aeromonas in accordance with

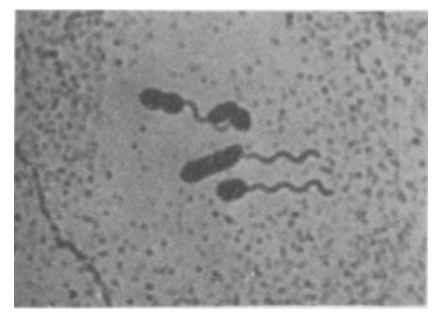

Fig. 1. Aeromonas hydrophila ATCC 7966. Cells possess a single, polar flagellum. Twenty-four-hour broth culture at $26 \mathrm{C}$. Staining by Leifson's method (Formalin-treated). $\times 1,200$. 
TABLE 1. Descriptions of Aeromonas hydrophila, of strains ATCC 7966 and ATCC 9071, and of Sanarelli's strain ${ }^{a}$

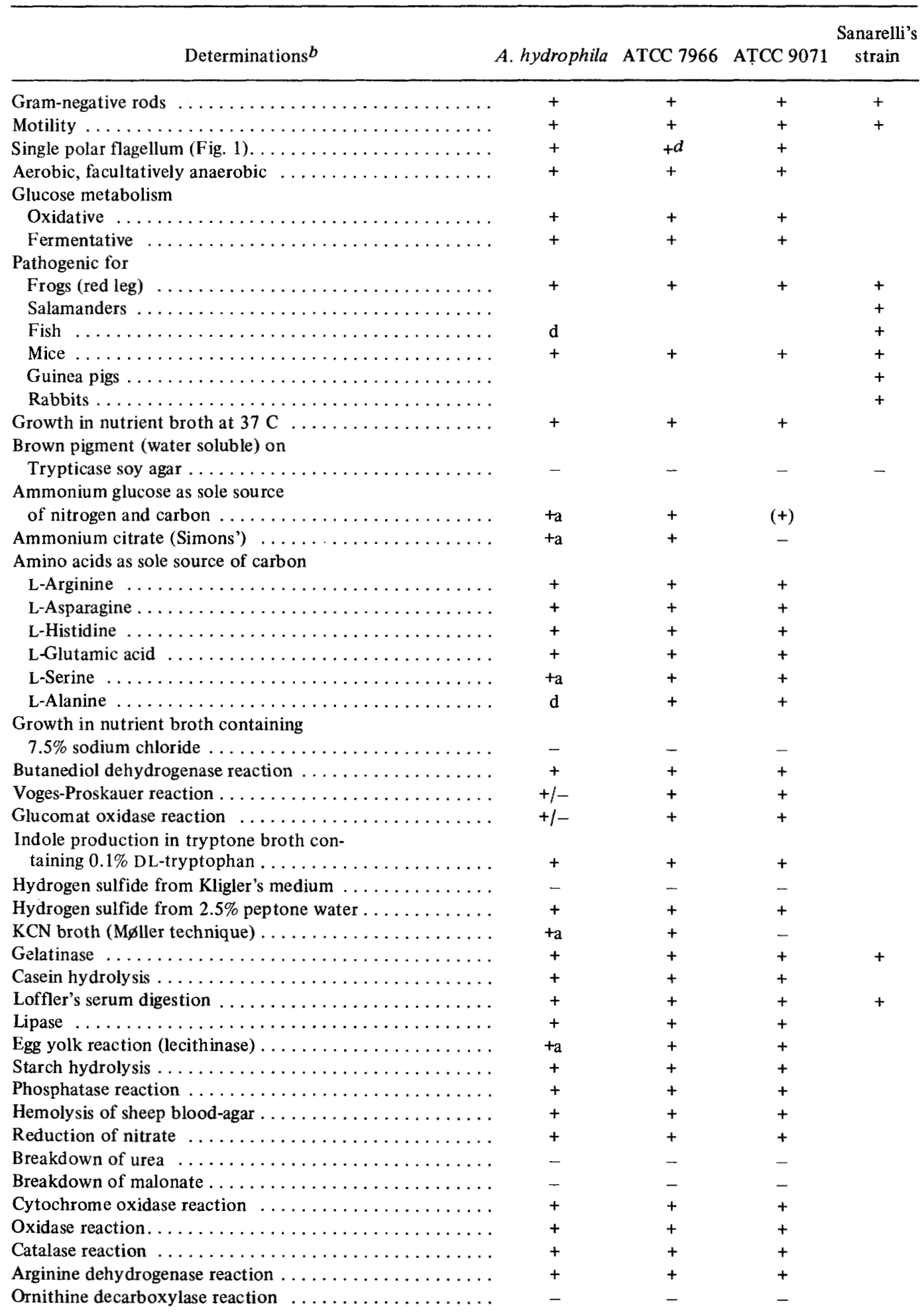


TABLE 1. Descriptions of Aeromonas hydrophila, of strains ATCC 7966 and ATCC 9071, and of Sanarelli's strain ${ }^{a}$ (Con't)

\begin{tabular}{|c|c|c|c|c|}
\hline Determinations $b$ & A. hydrophila & ATCC 7966 & ATCC 9071 & $\begin{array}{c}\text { Sanarelli's } \\
\text { strain }\end{array}$ \\
\hline Lysine decarboxylase reaction $\ldots \ldots \ldots \ldots \ldots \ldots$ & $\mathrm{d}$ & - & - & \\
\hline Phenylalanine deaminase reaction $\ldots \ldots \ldots \ldots \ldots$ & d & - & - & \\
\hline \multicolumn{5}{|l|}{ Breakdown of } \\
\hline 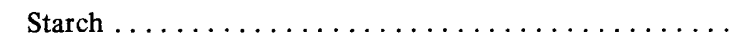 & AG & $\mathrm{AG}$ & AG & \\
\hline Dextrin $\ldots \ldots \ldots \ldots \ldots \ldots \ldots \ldots$ & AG & $\mathrm{AG}$ & AG & \\
\hline Glycogen $\ldots \ldots \ldots \ldots \ldots \ldots \ldots \ldots \ldots$ & AG & AG & AG & \\
\hline 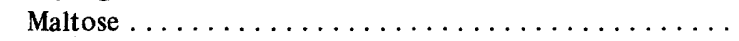 & AG & $\mathrm{AG}$ & AG & \\
\hline Trehalose $\ldots \ldots \ldots \ldots \ldots \ldots \ldots \ldots \ldots$ & AG & AG & AG & \\
\hline 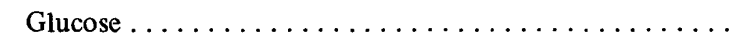 & AG & AG & AG & \\
\hline 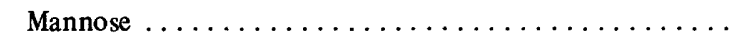 & AG & AG & AG & \\
\hline 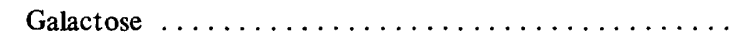 & AG & $\mathrm{AG}$ & AG & \\
\hline 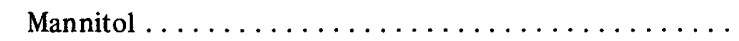 & AG & $\mathrm{AG}$ & AG & \\
\hline Fructose $\ldots \ldots \ldots \ldots \ldots \ldots \ldots \ldots \ldots$ & AG & AG & AG & \\
\hline Glycerol $\ldots \ldots \ldots \ldots \ldots \ldots \ldots \ldots \ldots \ldots \ldots \ldots \ldots \ldots \ldots$ & AG & AG & AG & $\mathrm{G}^{c}$ \\
\hline 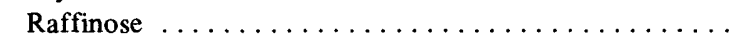 & $\mathrm{d}$ & - & - & \\
\hline 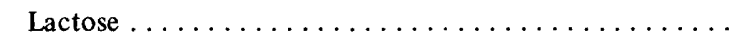 & d & $\mathrm{AG}$ & A & \\
\hline 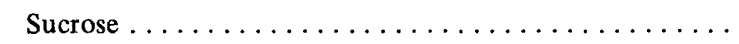 & $\mathrm{d}$ & AG & $A G$ & \\
\hline 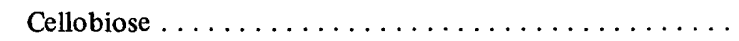 & $\mathrm{d}$ & - & - & \\
\hline 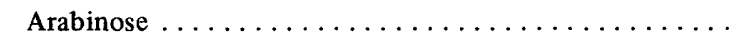 & $\mathrm{d}$ & - & AG & \\
\hline 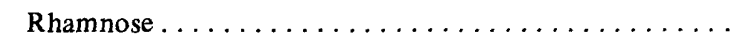 & d & - & - & \\
\hline 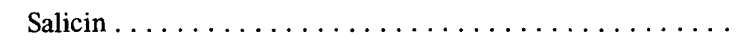 & $\mathrm{d}$ & - & - & \\
\hline 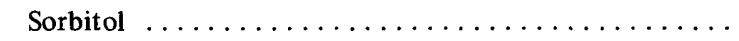 & $\mathrm{d}$ & - & - & \\
\hline 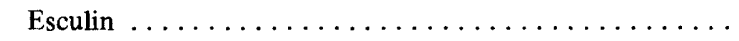 & $\mathrm{d}$ & A & - & \\
\hline 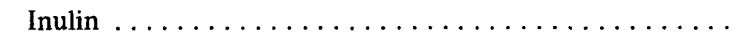 & - & - & - & \\
\hline 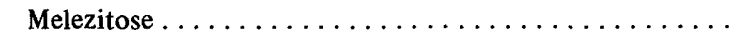 & - & - & - & \\
\hline 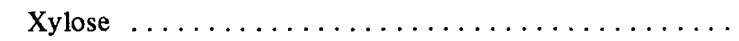 & - & - & - & \\
\hline 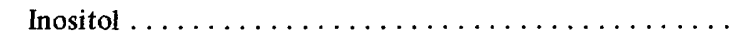 & - & - & - & \\
\hline 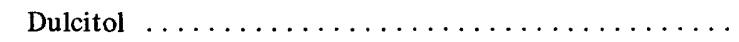 & - & - & - & \\
\hline 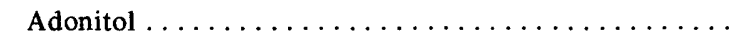 & - & - & - & \\
\hline Sensitivity to the vibriostatic agent $0 / 129 \ldots \ldots \ldots \ldots$ & - & - & - & \\
\hline
\end{tabular}

a Abbreviations: + , positive reaction; $(+)$, weak or delayed positive reaction; - , negative reaction; $\mathrm{A}$, acid production; $G$, gas production; a, aberrant strains occur; $d$, the reaction differs from strain to strain.

$b$ For descriptions of methods used to obtain the characteristics listed, see references 5-7.

$c$ Acid production not tested.

$d$ See Fig. 1 .

the provisions of Rule $9 \mathrm{c}(3)(\mathrm{c})$ of the International Code of Nomenclature of Bacteria (3), with a new type species, Aeromonas hydrophila (Chester 1901) Stanier 1943 (basionym: Bacillus hydrophilus Chester 1901). According to this rule, the generic name Aeromonas is to be attributed to Stanier, the author of the name of the type species, Aeromonas hydrophila.

None of the strains on which Sanarelli (4) based his original description of the organism now known as Aeromonas hydrophila are known to be extant. Consequently a neotype strain should be designated for $A$. hydrophila. Two different strains, ATCC 9071 and ATCC 7966, were suggested as the neotype, the former by Ewing et al. (2), the latter by
Schubert (7). However, in neither case was the Jucidial Commission asked to issue an opinion on the matter of a neotype strain for $A$. hydrophila, and consequently there is no official neotype strain for this organism. The rule $[9 \mathrm{~d}(1)(\mathrm{c})]$ of the International Code of Nomenclature of Bacteria that governs the establishment of neotype strains specifies, among other conditions, that (as of 1966, the date of publication of the latest version of the Code) a neotype strain must be proposed in the International Journal of Systematic Bacteriology and that the neotype becomes established from the date of publication in the Journal. Consequently, the two strains previously suggested as neotypes were compared to determine 
which should be designated here as the neotype. It was found that some of the characters of ATCC 9071 differ from those of the species A. hydrophila: ATCC 9071 does not grow on Møller's KCN broth or on Simmons' citrate agar, and the growth on a medium containing glucose and ammonia as sole sources of carbon and nitrogen is delayed; furthermore, Dyckmans (Ph.D. dissertation, Univ. of Bonn, 1969) showed that ATCC 9071 has a slower growth rate at low temperatures than do other strains of Aeromonas hydrophila. The characteristics which form the current concept of Aeromonas hydrophila and the characteristics of the strains ATCC 7966 and ATCC 9071 are presented for comparison in Table 1. This table also contains the characteristics of this organism as given by Sanarelli (4), which was the description on which Chester 1901 based his description of Bacillus hydrophilus.

From the data presented in Table 1, it is clear that both ATCC 9071 and ATCC 7966 agree with Sanarelli's original description. However, because the characteristics of ATCC 7966 are in better agreement with the current concept of $A$. hydrophila than are those of ATCC 9071, ATCC 7966 is here designated as the neotype strain of Aeromonas hydrophila (Chester) Stanier.

The Judicial Commission of the International Committee on Systematic Bacteriology is requested to issue an Opinion to place the name Aerobacter liquefaciens Beijerinck 1900 in the list of nomina rejicienda and to validate the generic name Aeromonas Stanier 1943 with the type species Aeromonas hydrophila (Chester 1901) Stanier 1943.

\section{ACKNOWLEDGMENT}

The assistance of $\mathrm{H}$. Hatt, American Type Culture Collection, who provided the photomicrographs of the flagellated cells, is gratefully acknowledged.

\section{LITERATURE CITED}

1. Chester, F. D. 1901. A manual of determinative bacteriology, The Macmillan Co., New York.

2. Ewing, W. H. and J. G. Johnson. 1961. Studies on the Aeromonas group. CDC Monogr., p. 1-37. Public Health Service, Communicable Disease Center, Atlanta, Ga.

3. International Code of Nomenclature of Bacteria. 1966. Int. J. Syst. Bacteriol. Parasitenk. 16:459490.

4. Sanarelli, G. 1891. Über einen neuen Mikroorganismus des Wassers, welcher für Tiere mit veränderlicher und konstanter Temperatur Pathogen ist. Centralbl. Bakteriol. Parasitenk. 9:193-199, $22-228$.

5. Schubert, R. H. W. 1960. Untersuchungen über die Merkmale der Gattung Aeromonas. Zentralbl. Bakteriol. Parasitenk. Orig. Abt. 1. 180:310-327.

6. Schubert, R. H. W. 1962. Zur Technik der Differenzierung von Vibrionen und Pseudomonaden mit dem Vibriostaticum 0/129. Zentralbl. Bakteriol. Parasitenk. Orig. Abt. 1. 184:560-561.

7. Schubert, R. H. W. 1964. Zur Taxonomie der Voges-Proskauer-negativen "hydrophilaähnlichen" Aeromonaden. Zentralbl. Bakteriol. Orig. Abt. 1 193:482-490.

8. Schubert, R. H. W. 1967 . The taxonomy and nomenclature of the genus Aeromonas Kluyver and van Niel 1936. I. Suggestions on the taxonomy and nomenclature of the aerogenic Aeromonas species. Int. J. Syst. Bacteriol. 17:23-27.

9. All specific and generic names are cited from (fully quoted in) R. E. Buchanan, J. G. Holt, and E. F. Lessel (ed.). 1966. Index Bergeyana. A companion to Bergey's manual of determinative bacteriology. The Williams \& Wilkins Co., Baltimore. 